\title{
Supernumerary Tooth in Lower Incisor Region: A Case Report
}

\author{
Djurica Grga, Bojan Dželetović \\ Department of Restorative Dentistry and Endodontics, School of Dentistry, University of Belgrade, Belgrade, Serbia
}

\begin{abstract}
SUMMARY
Supernumerary teeth are defined as any supplementary tooth in addition to usual configuration of twenty deciduous and thirty-two permanent teeth. They are most commonly found in the anterior maxilla and mandibular bicuspid region. Although supernumerary teeth have been reported in the incisor region of the mandible, they are very rare. It has been confirmed that approximately $25 \%$ of permanent supernumerary teeth appear in the mouth, the rest remains unerupted. The aim of this study was to present a case of single, erupted, supernumerary tooth in the right incisal region of the mandible. A patient showed up at the dental office complaining about aesthetic problem caused by a supernumerary tooth in mandibular incisal region. On intraoral examination, a supernumerary tooth, conical in shape and labially positioned, between the tooth 42 and 43, was observed. On previously taken panoramic radiogram, six months ago, the supernumerary tooth was undetected. Because the supernumerary tooth was masked by the denser overlying cortical bone, it was difficult to interpret the radiogram correctly. It should be noted that panoramic radiography does not guarantee accurate diagnosis of supernumerary teeth, therefore additional diagnostic methods are required.
\end{abstract}

Keywords: supernumerary teeth; canine

\section{INTRODUCTION}

Supernumerary teeth are defined as any supplementary tooth or tooth substance in addition to usual configuration of twenty deciduous and thirty-two permanent teeth [1]. They may occur as a single tooth or multiple teeth, unilaterally or bilaterally, in any region of the dental arch. According to the available literature the prevalence of supernumerary teeth in permanent dentition ranges from 0.1 to $3.8 \%$ in Caucasian population [2]. A slight difference in relative frequency of different supernumerary teeth, reported in the literature, can be attributed to the differences in sampling techniques, diagnostic criteria, age and ethnical groups examined [3]. Different prevalence

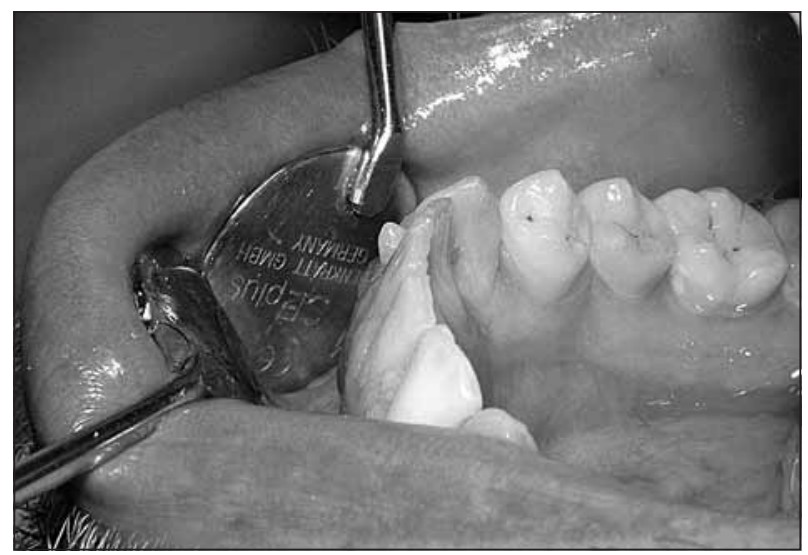

Figure 1. Supernumerary tooth labially positioned Slika 1. Labijalni položaj prekobrojnog zuba of supernumerary teeth has been reported in regards to gender with males being more commonly affected than females [4].

The incidence of supernumerary teeth is low and most commonly there is a single extra tooth. It has been confirmed that approximately $25 \%$ of permanent supernumerary teeth appear in the mouth, the rest remains unerupted [2]. They are most frequently found in the anterior maxilla and mandibular bicuspid region [5]. Although supernumerary teeth have been reported in the incisor region of the mandible, they are very rare $[6,7]$. The aim of this study was to present an adult patient having a single erupted supernumerary tooth, conical in shape, located in the incisal region of the mandible.

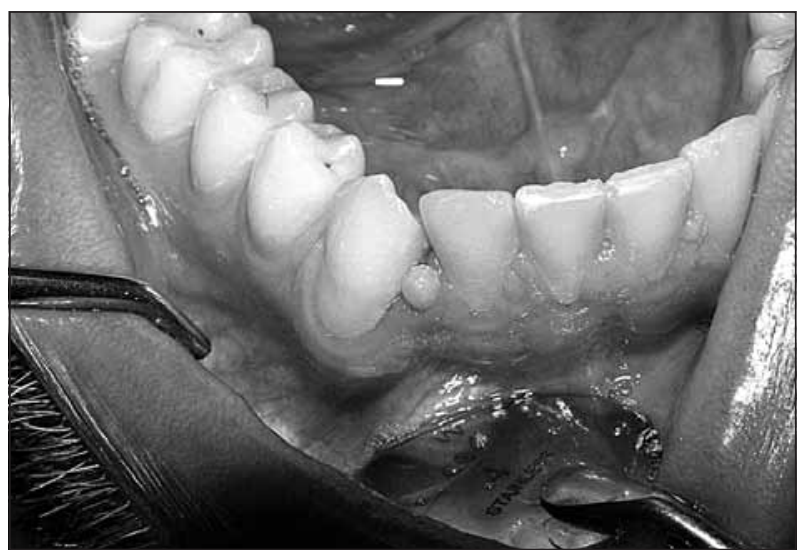

Figure 2. Supernumerary tooth from axial projection Slika 2. Prekobrojni zub iz aksijalne perspektive

Address for correspondence: Djurica GRGA, Dept. of Restorative Dentistry and Endodontics, School of Dentistry, 8 Dr Subotića St., 11000 Belgrade, Serbia; djuricag@eunet.rs 


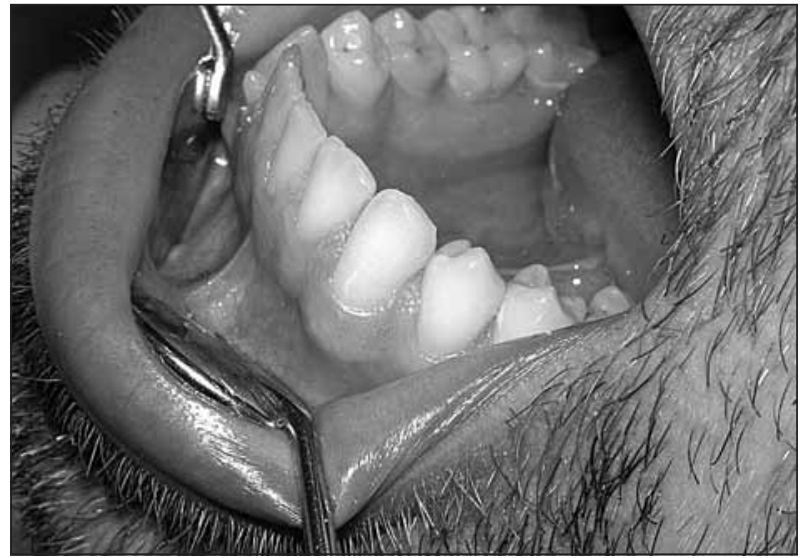

Figure 3. Teeth on the left side

Slika 3. Nalaz leve strane

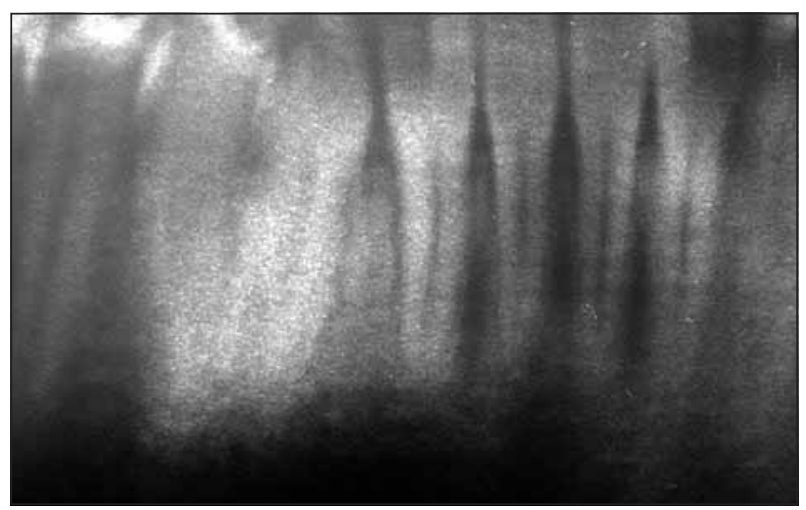

Figure 4. Retroalveolar radiogram before the extraction of the supernumerary tooth

Slika 4. Retroalveolarni snimak pre vađenja prekobrojnog zuba

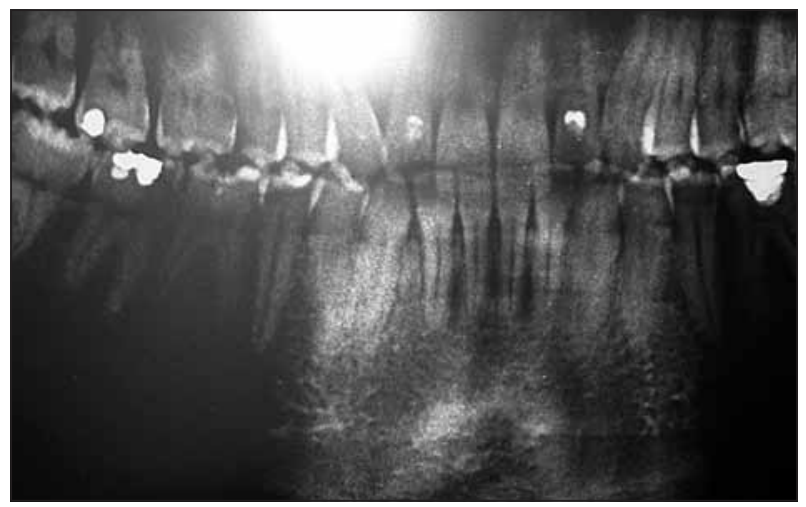

Figure 5. Ortopantomogram before extraction of the supernumerary tooth

Slika 5. Ortopantomogram pre vađenja prekobrojnog zuba

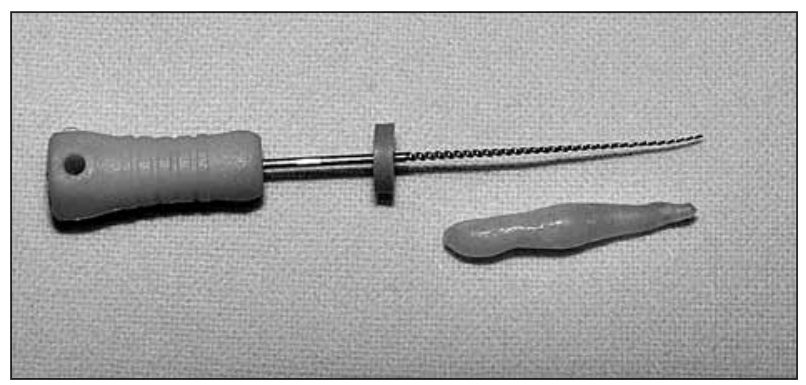

Figure 6. Supernumerary tooth after extraction Slika 6. Prekobrojni zub nakon vađenja

\section{CASE REPORT}

A 27-year-old male showed up at the dental office complaining of aesthetic and functional problems caused by an extra tooth in the anterior mandibular region. Medical and dental history did not reveal any important information regarding the presence of the supernumerary tooth. Extraorally, clinical finding was unremarkable. Intraoral examination confirmed that all teeth were present and restored. A presence of supernumerary tooth, conical in shape, between the tooth 42 and 43 , labially positioned was registered (Figure 1). Its crown was smaller in size compared to the neighboring teeth. A canine, next to it, was rotated and labially positioned compared to adjacent teeth (Figure 2). Surrounding soft tissue appeared normal with no detectable changes (Figure 3). Retroalveolar radiographic examination revealed complete root configuration of supernumerary tooth (Figure 4). On the panoramic radiogram taken six months ago, the supernumerary tooth was not detected because it was covered by the adjacent anatomical structures (Figure 5).

The treatment involved extraction of the supernumerary tooth under local anesthesia. The intervention was completed with no complication. The extracted tooth was $14.6 \mathrm{~mm}$ long and $3.6 \mathrm{~mm}$ wide (Figures 6 and 7 ). The root was wider in coronal and middle third while more gracile in the apical third with apex curved distally. An interesting point is that the tooth was covered by the enamel (9.1 $\mathrm{mm}$ ) up to the half (Figure 6). Radiography of the supernumerary tooth, taken after extraction, discovered the morphology of the root canal (Figure 8).

The follow-up confirmed proper healing. The patient was satisfied with the proposed therapy and achieved effect.

\section{DISCUSSION}

Classification of supernumerary teeth, according to the shape, considers four morphological types: conical, tubercular, supplemental teeth and odontomas. Traditionally,

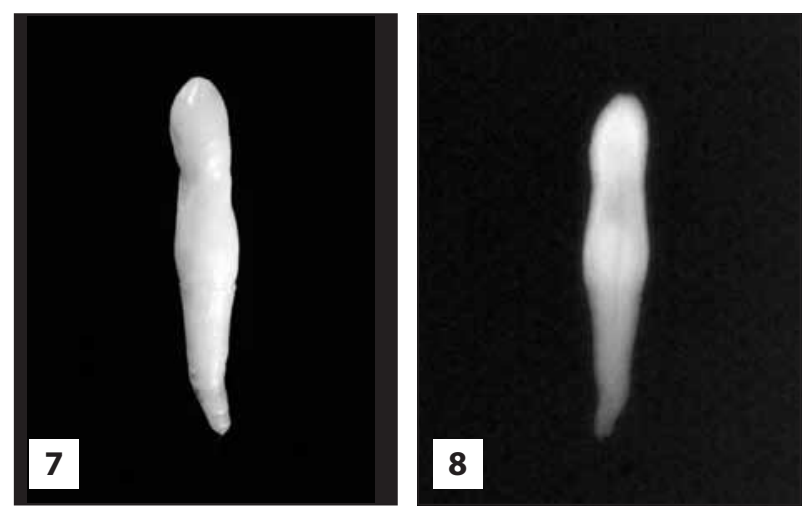

Figure 7. Anatomomorphology of extracted supernumerary tooth Slika 7. Anatomomorfologija izvađenog prekobrojnog zuba

Figure 8. Radiography of extracted supernumerary tooth with clearly visible root canal structure

Slika 8. Rendgenski snimak izvađenog prekobrojnog zuba s jasno vidljivom unutrašnjom građom 
odontomas have been classified as benign odontogenic tumors [8]. Although not generally accepted, some authors believe that odontomas are developmental anomalies that contain fully formed enamel and dentin [9]. Supernumerary teeth may cause clinical problems such as impaction, malposition, rotation, crowding, diastema, root resorption of adjacent teeth or cyst formation $[5,10,11,12]$. In cases where supernumerary teeth neither erupt nor cause any complication they can be discovered accidentally by a radiogram.

The existence of supernumerary teeth is poorly understood. However, several theories have been proposed. Smith [13] explained the development of supernumerary teeth as the phylogenetic process of atavism. Several authors considered the environmental factors and dichotomy of the tooth germ in etiology of supernumerary teeth $[14,15,16]$. The localized hyperactivity of the dental lamina was believed to be an important etiological factor for the development of supernumerary teeth $[10,15,17]$. The etiology of supernumerary teeth may be partially genetic as they appear more frequently in relatives of affected individuals than in general population [5]. Also, supernumerary teeth can be found in syndromes such as Cleidocranial Dysostosis or Gardner's Syndrome [3]. Scheiner and Sampson [4] suggested that careful family medical history assessment regarding the supernumerary teeth can reveal possible presence of a genetically determined syndrome.

Early diagnosis in patients who have supernumerary teeth is important to prevent or minimize complications. Appropriate radiography is indispensable in early diagnosis of supernumerary teeth. Some authors recommend a panoramic radiography as the most useful screening method because it shows all areas of the maxilla and mandible $[4,18]$. In the case report from the current study, the panoramic radiogram taken six months earlier had limited diagnostic value. The supernumerary tooth was masked by denser overlying cortical bone and adjacent canine root making radiogram difficult to interpret.

Early diagnosis of supernumerary teeth and optimal treatment plan are important to prevent complications. However, it should be noted that panoramic radiography can suggest the existence of supernumerary teeth but it does not guarantee accurate diagnosis of the same.

\section{REFERENCES}

1. Schulze C. Developmental abnormalities of the teeth and jaws. In: Gorlin RJ, Goldman HM, editors. Thoma's Oral Pathology. St Louis: Mosby; 1970. p.112-22.

2. Rajab LD, Hamdan MAM. Supernumerary teeth: review of the literature and a survey of 152 cases. Int J Paed Dent. 2002; 12:244-54.

3. Zhu JF, Marcushamer M, King DL, Henry RJ. Supernumerary and congenitally absent teeth: a literature review. J Clin Pediat Dentist. 1996; 20:87-95.

4. Scheiner MA, Sampson WJ. Supernumerary teeth: a review of the literature and four case reports. Aust Dent J. 1997; 42:(3):160-5.

5. Mitchell L. Supernumerary teeth. Dent Update. 1989; 16:65-9.

6. Tanaka S, Murakami Y, Fukami M, Nakano K, Fujisawa S, Miyoshi $\mathrm{S}$. A rare case of bilateral supernumerary teeth in the mandibular incisors. Br Dent J. 1998; 185:386-8.

7. Fukuta Y, Totsuka M, Takeda Y, Yamamoto H. Supernumerary teeth with eumorphism in the lower incisor region: a report of five cases and review of the literature. J Oral Sci. 1999; 41:199-202.

8. Kramar IRH, Pindborg J), Shear M. World Health Organization International Histological Classification of Tumours - Histological Typing of Odontogenic Tumours. 2nd ed. Berlin, Heidelberg: Springer-Verlag; 1992.

9. Soames JV, Southam JC. Oral Pathology. 3rd ed. New York: Oxford University Press; 1998.

10. Primosch R. Anterior supernumerary teeth - assessment and surgical intervention in children. Ped Dent. 1981; 3:204-15.

11. Hattab FN, Yassin OM, Rawashdeh MA. Supernumerary teeth: report of three cases and review of the literature. ASDC J Dent Child. 1994; 61:382-93.

12. Zilberman Y, Marlon M, Shteyer A. Assessment of 100 children in Jerusalem with supernumerary teeth in the premaxillary region. ASDC J Dent Child. 1992; 59:44-7.

13. Smith JD. Hyperdontia: report of case. J Am Dent Assoc. 1969; 79:1191-2.

14. Shapira Y, Kuftenic MM. Multiple supernumerary teeth: report of two cases. Am J Dent. 1989; 2:28-30.

15. Liu JF. Characteristics of premaxillary supernumerary teeth: a survey of 112 cases. ASDC J Dent Child. 1995; 62:262-5.

16. Stellzig A, Basdra EK, Komposch G. Mesiodentes: incidence, morphology, etiology. J Orof Orthop. 1997; 58:144-53.

17. Sykaras SN. Mesiodens in primary and permanent dentition. Oral Surg Oral Med Oral Pathol. 1975; 39:870-4.

18. Tomić S, Janković S, Smrekić B, Djordjević S. The consequences of an untimely diagnosed mesiodens - case report. Stomatološki glasnik Srbije. 2007; 54:248-53.

Received: $12 / 07 / 2010 \cdot$ Accepted: 01/10/2010 


\title{
Prekobrojni zub u predelu inciziva donje vilice - prikaz slučaja
}

\author{
Đurica Grga, Bojan Dželetović \\ Klinika za bolesti zuba, Stomatološki fakultet, Univerzitet u Beogradu, Beograd, Srbija
}

\begin{abstract}
KRATAK SADRŽAJ
Kao prekobrojni može se definisati svaki zub koji se javi kao višak u odnosu na uobičajenu konfiguraciju od dvadeset mlečnih zuba i trideset dva stalna zuba. Prekobrojni zubi se najčešće javljaju u prednjem delu gornje vilice i predelu pretkutnjaka donje vilice. lako su poznati slučajevi prekobrojnih zuba u predelu sekutića donje vilice, oni se retko javljaju. Pokazano je da oko $25 \%$ prekobrojnih zuba stalne denticije niče, dok ostali ostaju impaktirani. Cilj ovog rada je bio da se kod odraslog muškarca prikaže slučaj prekobrojnog zuba koji je iznikao u predelu sekutića donje vilice. Pacijent se javio zbog estetskih problema izazvanih dodatnim nicanjem donjeg prednjeg zuba. Intraoralno, u predelu između zuba 42 i 43, mogao se uočiti labijalno pozicioniran prekobrojni zub koničnog oblika. Na ortopantomogramu načinjenom šest meseci ranije ovaj prekobrojni zub nije zapažen. $S$ obzirom na to da se prekobrojni zub superponirao s kortikalnom kosti, bilo je otežano ispravno tumačenje snimka. S obzirom na to da ortopantomografski snimci ne garantuju uvek preciznu dijagnozu prekobrojnih zuba, za kliničku dijagnozu je neophodno preduzeti i dodatne dijagnostičke postupke.
\end{abstract}

Ključne reči: prekobrojni zubi; očnjak

\section{UVOD}

Zubi koji se javljaju kao višak u odnosu na uobičajenu konfiguraciju od dvadeset mlečnih zuba i trideset dva stalna zuba definišu se kao prekobrojni zubi [1]. Mogu se javiti kao jedan ili više zuba istovremeno, i to jednostrano ili obostrano u bilo kojem delu zubnog luka. Prema podacima iz literature, učestalost prekobrojnih zuba u opštoj populaciji bele rase u stalnoj denticiji je $0,1-3,8 \%$ [2]. Izvesne razlike u učestalosti pojedinih tipova prekobrojnih zuba mogu se objasniti razlikama u korišćenim uzorcima, dijagnostičkim kriterijumima, starosti i rasi ispitanika [3]. Istraživači su otkrili razlike u učestalosti i između polova. Ustanovljeno je da se prekobrojni zubi češće javljaju kod osoba muškog pola [4].

Prekobrojni zubi se obično javljaju kao pojedinačni nalaz, a stopa njihovog nicanja je veoma mala. Dokazano je da svega oko $25 \%$ svih otkrivenih prekobrojnih zuba stalne denticije iznikne, dok ostali uglavnom ostaju impaktirani [2]. Prekobrojni zubi se najčešće javljaju u prednjem delu gornje vilice i u predelu pretkutnjaka donje vilice [5]. Poznati su slučajevi prekobrojnih zuba i u predelu sekutića donje vilice, ali se oni ređe javljaju [6, 7]. Cilj ovog rada je bio da se kod odraslog muškarca prikaže slučaj koničnog prekobrojnog zuba koji je iznikao u predelu sekutića donje vilice.

\section{PRIKAZ SLUČAJA}

Dvadesetsedmogodišnji muškarac se javio stomatologu zbog estetskih i funkcionalnih smetnji izazvanih nicanjem prekobrojnog donjeg prednjeg zuba. Opšta medicinska i stomatološka anamneza nisu dale podatke značajne za trenutno stanje. Ekstraoralnim pregledom utvrđen je normalan stomatološki nalaz. Intraoralno je takođe utvrđen normalan stomatološki nalaz, s korektno saniranim zubima. U predelu između zuba 42 i 43, sa desne strane, uočen je labijalno pozicioniran prekobrojni zub koničnog oblika (Slika 1) znatno manjih dimenzija od susednih zuba. Susedni očnjak je bio rotiran i nešto labijalnije postavljen u odnosu na ostale zube (Slika 2). Pregledom mekotkivnih struktura nisu uočene druge promene (Slika 3).
Retroalveolarni radiogram ovoga zuba je pokazao konfiguraciju korena prekobrojnog zuba (Slika 4). Na ortopantomogramu načinjenom šest meseci ranije prekobrojni zub nije prepoznat, jer se uklapao u susedne anatomske strukture (Slika 5).

Plan lečenja je podrazumevao vađenje prekobrojnog zuba u lokalnoj anesteziji. Intervencija je protekla bez komplikacija. Izvađeni zub je bio dugačak 14,6 mm, a širok 3,6 mm (Slike 6 i 7). Korenski deo je imao širu koronarnu i srednju trećinu, da bi u apikalnoj trećini prešao u gracilniji oblik sa distalnim zakrivljenjem. Zanimljivo je da je zub do polovine $(9,1 \mathrm{~mm})$ bio prekriven gleđju (Slika 6). Posebno je zanimljiv rendgenogram zuba posle ekstrakcije na kojem se jasno uočava morfologija endodontskog prostora (Slika 8).

Kontrolni klinički pregled je potvrdio normalno zarastanje mekih tkiva. Pacijent je bio zadovoljan tokom i brzinom intervencije i postignutim rezultatima.

\section{DISKUSIJA}

Na osnovu oblika, prekobrojni zubi se mogu klasifikovati na četiri tipa: konični, tuberkulumski, saplementni i u vidu odontoma. Tradicionalno, odontomi se svrstavaju u grupu benignih odontogenih tumora [8]. Međutim, iako takav stav nije opšteprihvaćen, neki autori veruju da su odontomi razvojne anomalije koje se sastoje od potpuno formiranih tkiva gleđi i dentina [9]. Prekobrojni zubi mogu izazvati razne kliničke probleme, poput impakcija, malpozicija, rotacija, teskoba, stvaranja dijasteme, resorpcije korena susednih zuba i formiranja cisti $[5,10$, $11,12]$. Kada ne uspeju da izniknu i pri tom ne izazovu kliničke komplikacije, prekobrojni zubi se mogu otkriti kao usputni radiografski nalaz.

Uzroci pojave prekobrojnih zuba nisu potpuno razjašnjeni, ali u literaturi postoji nekoliko teorija. Smit (Smith) [13] je filogenetskim procesom atavizma objasnio razvoj ovih zuba. Nekoliko autora je razmatralo ulogu faktora sredine i dihotomiju zubnog zametka u nastanku ove pojave $[14,15,16]$. Jedan broj istraživača smatra da je lokalizovana hiperaktivnost zubne gredice značajan etiološki faktor u razvoju prekobrojnih zuba $[10,15,17]$. Veća učestalost među srodnicima nego u opštoj 
populaciji ukazuje na mogućnost učešća genetskog nasleđa u etiologiji [5]. Takođe, prekobrojni zubi se mogu javiti kao deo pojedinih sindroma, kao što su kleidokranijalna dizostoza ili Gardnerov sindrom [3]. Šajner (Scheiner) i Sampson (Sampson) [4] su zaključili da sumnja na pojavu sindroma može biti $\mathrm{u}$ vezi s podacima o prekobrojnim zubima prikupljenim iz porodične anamneze.

Rana dijagnoza prekobrojnih zuba je značajna za prevenciju i smanjenje potencijalnih komplikacija. Za pravovremeno postavljanje dijagnoze neophodna je kvalitetna radiografija. Neki autori preporučuju ortopantomografiju kao najbolju skrining-metodu za otkrivanje ovih zuba, jer omogućava prikazivanje svih delova vilica $[4,18]$. U prikazanom slučaju ortopantomogram načinjen šest meseci pre vađenja prekobrojnog zuba imao je ograničenu dijagnostičku vrednost. S obzirom na to da se prekobrojni zub superponirao s kortikalnom kosti i delom korena zuba 43, bilo je otežano ispravno tumačenje snimka.

Rana dijagnostika prekobrojnih zuba i adekvatan plan lečenja uslovi su za sprečavanje nastanka mogućih komplikacija. Treba imati u vidu da ortopantomografski snimci mogu ukazati na postojanje prekobrojnih zuba, ali ne moraju uvek biti dragoceni za preciznu dijagnozu. 